Para enlazar con este artículo / To link to this article:

https://doi.org/10.6035/MonTI.2020.12.12

Para citar este artículo / To cite this article:

Bernabé Caro, Rocío. (2020) "New taxonomy of easy-to-understand access services." In: Richart-Marset, Mabel \& Francesca Calamita (eds.) 2020. Traducción y Accesibilidad en los medios de comunicación: de la teoría a la práctica. MonTI 12, pp. 345-380.

\title{
NEW TAXONOMY OF EASY-TO-UNDERSTAND ACCESS SERVICES ${ }^{1}$
}

\author{
ROCÍO BERNABÉ CARO \\ rocio.bernabe@sdi-muenchen.de \\ SDI München, University of Applied Languages
}

\begin{abstract}
The Convention on the Rights of People with Disabilities states that access to information through written and electronic communications is essential for personal development and full participation in society. In digital scenarios, media services, such as audio descriptions, subtitles, or sign language, facilitate access to content with a focus on sensory barriers. Still, there are shortcomings in addressing other needs, such as cognitive ones. This article aims to suggest a taxonomy of the emerging easy-to-understand access services that cater for the needs of audiences who struggle with understanding audiovisual content for varied reasons, such as low literacy, reading or learning difficulties, temporary impairments, or insufficient language skills. The taxonomy uses Gottlieb's (2005) semiotically-based classification to define E2U access services within the landscape of Audiovisual translation and to classify them according to their semiotic identity as compared to the standard access services.
\end{abstract}

Keywords: Cognitive accessibility; Easy to Read. Plain Language; Text simplification; Easy-to-understand accessibility services.

1. This article has been partially funded by the EU project IMAC grant number 761974 , EASIT 2018-1-ES01-KA203-050275, RAD PGC2018-096566-B-I00 and the Catalan Research Council grant number SGR113. 


\section{Resumen}

La Convención sobre los Derechos de las Personas con Discapacidad establece que el acceso a la información escrita y electrónica es esencial para el desarrollo personal y una participación social plena. En escenarios digitales, los servicios de accesibilidad como la audiodescripción, el subtitulado o la lengua de signos facilitan dicho acceso, especialmente en el caso de barreras sensoriales. Sin embargo, en el ámbito cognitivo aún quedan barreras por salvar. Este artículo presenta una taxonomía de servicios de accesibilidad que usan métodos de simplificación para facilitar el acceso a personas con dificultades de comprensión, ya sea por problemas de lectura, aprendizaje, discapacidad temporal o niveles insuficientes de lengua. La taxonomía presentada utiliza la clasificación semiótica de Gottlieb (2005) para ubicar estos servicios de accesibilidad dentro de la traducción audiovisual y para clasificarlos según su identidad semiótica en comparación con los servicios de accesibilidad estándar.

Palabras clave: Accesibilidad cognitiva; Lectura fácil; Lenguaje llano; Simplificación textual; Servicios de accesibilidad fáciles de comprender.

\section{Introduction}

Audiovisual text is conveyed by both audio and visual channels. Viewers listen and view the information as they begin to decode the message and create meaning. In this process, sensory reception and language skills seem to be critical. Hence, if challenged, understanding and communication could be at stake.

The Audiovisual Translation (AVT) modes subtitling and dubbing emerged to overcome language barriers. Today, the AVT landscape has expanded and includes access services to address the needs of audiences with sensory disabilities. For instance, audio descriptions render content aurally that would usually only be conveyed visually. Similarly, intralingual subtitles provide audiences with hearing loss with written translations of the spoken text.

The question arising is whether audiovisual content provided by these access services is also cognitively accessible for audiences such as: (a) users who can see but struggle reading or understanding written content; (b) users who can see and hear but have difficulties understanding content; and (c) users with multiple needs: for instance, a user may have hearing loss and also have problems reading subtitles or a user with visual loss may have difficulties understanding a dense audio description that is provided as an alternative. 
Until today, there is no common definition of cognitive accessibility (Johansson 2016), although it has been studied from many perspectives such as linguistics (Siddharthan 2014; Arfé, Mason \& Fajardo 2017), web accessibility and digital inclusion (Sevilla, Martínez \& Alcantud 2007; COGA 2018), inclusion (Verdugo \& Schalock 2010), education (Vived \& Molina 2012; Belinchón, Casas, Díez \& Tamarit 2014), information design (Johansson 2016), computer science (Shardlow 2014), accessible cities (CEAPAT 2015), and e-learning (Olivetti Belardinelli 2008). In the field of AVT, new so-called easy-to-understand (E2U) or easy services are now being described (Bernabé \& Orero 2019).

These E2U access services depart from the standard access services and use simplification methods such as Plain Language (PL) or Easy to Read (E2R) to enhance cognitive accessibility of audiovisual content. For instance, E2U audio descriptions (Bernabé \& Orero forthcoming), E2U subtitles (Bernabé et al. forthcoming; Oncins et al. 2020), and simplified respeaking (Eugeni 2017). Research within AVT Studies is now also being conducted, e.g., in the EU co-funded EASIT project, ${ }^{2}$ which is catering for the need for training material and recommendations to create easy-to-understand audiovisual content, and the EU H2020 project ImAc, ${ }^{3}$ which is currently testing the reception of E2R subtitles in immersive contexts. All these efforts and approaches share the goal of improving cognitive accessibility, which Johansson (2016: 20) defines as follows:

Cognitive accessibility is the extent to which products, systems, services, environments and facilities can be used by people from a population with the widest range of cognitive characteristics and capabilities to achieve a specified goal in a specified context of use.

A legitimate question at this stage would be whether E2U access services are exactly equivalent to the standard access services they emerge from and, thus, only differ in the use of a "more simple language" or whether they display idiosyncratic features and have their place within AVT. To answer this question, this article explores the semiotic composition of E2U access services as compared to their standard counterparts. To this end, it departs

2. http://pagines.uab.cat/easit/en

3. http://www.imac-project.eu/ 
from Gottlieb's (2005) taxonomy and draws upon both the previous definitions and the presumption that cognitive characteristics of standard access services-or more generically audiovisual content-are modifiable. This singularity provides leverage to enhance their cognitive accessibility when they are designed according to valid guidelines, such as WCAG as proposed by Johansson (2016), and according to simplification guidelines and recommendations, such as PL and E2R as it is suggested in this article.

\section{Easy-to-understand meets Audiovisual Translation}

The term "easy-to-understand" is used in this article as an umbrella term to describe content, methods, products, or services that rely on text or graphical simplification to enhance their cognitive accessibility during the interaction with the user. In this sense, E2U access services provide audiovisual content through E2U-designed access services. The overall goal pursued is to make audiovisual content accessible to audiences with the widest range of cognitive characteristics and capabilities.

Because interaction begins at an early stage, with users navigating and browsing through search engines, menus, and options before they reach the actual audiovisual content, E2U access services must approach accessibility throughout the entire provision chain. This broader definition of access services is in line with Articles 9 and 21 of the Convention on the Rights of Persons with Disabilities (CRPD) (United Nations 2006) and also endorses the view that accessibility should encompass content, design, and technology. This article defines E2U access services in these terms and expands on how these demands can be taken into consideration in Section 3.

Simplification, text reduction, reformulation, condensation, omissions, and decimation are terms already attached to the field of Audiovisual Translation (AVT). They relate to the way different access services overcome textual, situational, or technical constraints. For instance, space or time restrictions in subtitles (Gottlieb 1992, 2005; Marinetti 2012); speech-related challenges in real-time, intralingual subtitling (Eugeni 2008; Eugeni \& Bernabé 2020); or genre-related constraints, as is the case in audio descriptions

4. This term has already been used by Inclusion Europe (2009), IFLA (2010) and is equivalent to the term "easy" introduced by Bernabé \& Orero (2019). 
for children or young audiences (Orero 2011). Though standard access services use such simplification strategies to support understandability, their focus is to provide an alternative way of conveying content when one of the main channels, visual or aural, are challenged. Conversely, in this article, it is presumed that E2U access services subordinate visual or aural accessibility to cognitive accessibility and, thus, are not functionally equivalent with their standard counterparts.

As translations that derive from standard access services, E2U content aligns with translation approaches that allow for the incorporation of "alterations and new perspectives" (Díaz Cintas 2004: 31), consider "audiences with different socio-cultural and socio-linguistic backgrounds and expectations" (Gambier 2003: 178), and allow for wider understanding of translation beyond an "interlingual, conventionalised and isosemiotic translation" (Gottlieb 2005: 43). These perspectives are, for instance, Transadaptation (Gambier 2003), Descriptive Translation Studies (Holmes 1972; Toury 1995; Díaz Cintas 2004), or Multidimensional Translation (Gerzymisch-Arbogast 2005; Gottblieb 2005; Gerzymisch-Arbogast 2007).

According to the semiotically based parameters provided by Gottlieb's, E2U content can be classified as translations that (a) comprise types of communication "not involving language in a traditional way", (b) act as "text enhancers" and focus on how the target texts are cognitively perceived, and (c) acknowledge the translation product as "more free" and "less predictable" (Gottlieb 2005: 33, 37).

As for their non-standard use of language, Plain Language and Easy to Read converge with the semiotic approach in two ways. First, in its view of "language" as an "animate communicative system working through the combination of sensory signs", meaning verbal and nonverbal elements (Gottlieb 2005: 35). PL and E2R rely on verbal codes, paratextual and prosodic features (e.g., typographical choices, intonation, speed of voice), and nonverbal elements (e.g., nonverbal illustrations, pictograms, or ideograms). Second, PL and E2R deviate from standard use and style recommendations. For instance, both build upon the use of repetition (e.g., lexical and syntactical), short sentences, explicitness, and syntactic redundancy (Inclusion Europe 2009; PLAIN 2011). 
As for the cognitive reception of texts, E2U access services address audiences that need support by decoding and understanding the content for various reasons. They act as text enhancers that support understandability in different ways. For instance, by reducing the terminological or syntactic load, by adding linguistic information or nonverbal elements to either make the message more explicit or to activate prior knowledge (Arfe, Mason \& Fajardo 2017; Wengelin 2019), or by providing knowledge that is considered as presupposed. These enhancing strategies draw upon the assumption that removing linguistic complexity on a lexical or grammatical level alone does not necessarily aid (inferential) comprehension, as shown in young or poor readers (di Mascio, Gennari \& Vittorini 2011) and L2 learners (Urano 2000). In Translation, these strategies to secure cohesion are referred to as universals of translation (Laviosa-Brathwaite 2001).

To sum up, in this article simplification is considered both reductive and additive. Thus, E2U translations are considered to act as "text enhancers" and "thus boosting the impact of the original figures [texts], which on their own terms may not be cognitively, fully comprehensible to the audience" (Gottlieb 2005: 37). This primary role as text enhancers does not exclude the other functions attributed by Gottlieb (2005) to translations: text substitutes, translations crossovers, or supplements. However, this taxonomy subordinates them to their primary role of E2U content as text enhancers.

As for the extent to which E2U translations are "more free" and "less predictable", translations that use sets of "rules" are considered in Gottlieb's taxonomy as "conventionalised" translations (Gottlieb 2005: 36). As such, they are predictable and closer to the original, and allow "reconstruct[ing] the original from the translated version [...] - to a certain extent". Though the creation of E2U translations adheres to the guidelines and recommendations of PL and E2R, it would not be possible to reconstruct the source text after simplification. And, thus, E2U translations are considered inspirational translations.

All things considered, the AVT landscape can expand and incorporate easy access services (Bernabé \& Orero 2019), which both originate from their standard counterparts (e.g., audio descriptions, subtitles) and deviate from them to fulfil their function as "text enhancers" (Gottlieb 2005: 37). As translations, E2U access services are inspirational, however, regulated by 
recommendations and guidelines arising from: (a) text simplification guidelines and recommendations; (b) guidelines governing the underlying standard access service (e.g., audio description or subtitling guidelines), and (c) digital accessibility guidelines as explained in section 3 . The differences with the standard access services arise from a non-standard use of language and an idiosyncratic and combined use of semiotic codes (verbal and nonverbal), which include elaborating or adding new elements to make audiovisual content cognitively more accessible.

The next section explores the use of simplification methods to create E2U content for access services.

\subsection{Standard access services meet simplification methods}

Simplification methods can make content more cognitively accessible (Arfe, Mason \& Fajardo 2017) and, thus, reduce the cognitive load that users experience during the interaction. These methods can be classified as verbal or nonverbal based on the semiotic codes they use.

As for verbal simplification methods, they can be classified into text simplification methods or easifications. Text simplification methods modify the original text manually or automatically, by either reducing their linguistic complexity, adding linguistic information, or by text elaboration (García 2012; Siddharthan 2014). Conversely, easifications maintain the unchanged original and provide readers with so-called "easification devices". These devices are organisation strategies (e.g., restructuring, reorganising, rearranging) for presenting the text "without in any way modifying or mutilating the lexis or the syntax of the text" (Bathia 1983). Lastly, as for nonverbal simplification methods, they rely on graphical symbols such as pictograms or ideograms (Tuset et al. 2011).

The classification provided in this section considers two verbal methods-Plain Language and Easy to Read- and also nonverbal simplification through graphical-symbols, whereas it excludes easification for three main reasons. First, the use of easification devices would not be viable, for instance, in TV shows or movies; second, they will hinder enjoyment; and, third, they would exclude simplification in real-time and live situations. Nonetheless, text simplification also bears risks as pointed out by Bathia (1983), since it is 
based on assumptions made by the adapter, the changes in lexis and elaborations may not fully transfer the original meaning, and it does not help readers to develop their own coping strategies for a specific text.

Plain language and Easy to Read are both text simplification methods that aim to make information accessible and to enable self-determination and self-advocacy (Cornelius 2010). They have emerged to cover needs arising from two different fields. The Plain Language Action and Information Network (PLAIN) states "Plain Language is communication your audience can understand the first time they read or hear it." (PLAIN, n.d.). Plain Language emerged in the United States in the past century triggered by the need for "making legal, government, and economic texts accessible to lay-readers" (García 2012). PL development was top-down, promoted by the Government and supported by financial institutions that were facing legal suits coming from consumer associations (Berent 2010). As a method, Plain Language builds on recommendations related to the design and linguistic simplification-syntax, grammar and lexis.

Conversely, the development of E2R was bottom-up and triggered by end-user associations, such as People First in the United States in the 70s, to protect and promote the rights of people with diverse intellectual and learning capabilities. In Europe, the umbrella end-users association Inclusion Europe (IE) has been working since 1988 towards the same goals. Its efforts led to the Easy to Read guidelines Information for All in 2009, which are available in 16 languages. As opposed to Plain Language, Easy to Read primarily targets the needs of persons with diverse intellectual and learning capabilities (IFLA 2010; Inclusion Europe 2009).

The document entitled Guidelines for easy-to-read materials by the International Federation of Library Association and Institutions (IFLA) provides two definitions of the term Easy to Read and explicitly relates to the second one (IFLA 2010: 3):

One means a linguistic adaptation of a text that makes it easier to read than the average text but which does not make it easier to comprehend; the other definition means an adaptation that makes both reading and comprehension easier.

Both definitions draw upon three main underlying concepts: legibility, readability, and understandability. Legibility is related to the first interaction 
between the reader and paratextual elements, as defined by Tinker (1963). Legibility parameters are design-related, language-independent, and range from typographical variables such as font-size or font-type to layout ratios such as contrast or the ratio of text to white space (Inclusion Europe 2009; Yuste Frías 2012; Nietzio, Naber \& Bühler 2014). Readability is a wider concept. It relates to linguistic parameters that make a text more or less complex, but also to legibility (Burtt 1949; European Commision 2019; Siddharthan 2014; Fajardo et al. 2014). Lastly, understandability refers to the personal ability of a reader to infer meaning from a text (e.g., literal, inferential) (Siddharthan 2014). Understandability depends on external variables (e.g., light, brightness, background noise) and intrinsic ones such as reader motivation and prior knowledge.

According to these definitions, readability is extrinsic to the reader and influences the individual resources dedicated to the decoding task (Brueggeman 2000). Readability can be improved by manual and automatic simplification methods (García 2012; Shardlow 2014), whereas understandability is intrinsic to the user and depends on "the reader's familiarity with the source vocabulary, their understanding of key concepts, or time and care that were taken to read the text" (Siddharthan 2014). In this article, these concepts are defined in these terms

In summary, E2R and PL are text simplification methods based on paratextual and linguistic rules and recommendations that aim to improve readability and to support understandability. They can therefore be used to enhance the cognitive accessibility of AV content. The resulting E2U content would be verbal as opposed to nonverbal content, which would rely on graphical symbols. ${ }^{5}$

To the author's knowledge, pictogram methods do not yet exist as E2U nonverbal access services. However, there are already digital products (e.g., web applications, software) that use this form of nonverbal mediation: for instance, Text2Pic, Proloquo2Go, iPicto, Pict-Net, and AraBoard. In AVT, the use of graphical symbols has been studied in subtitles for the Deaf and

5. For simplification purposes, the term pictogram is used to refer to graphical symbols, pictograms, and ideograms. 
hard-of-hearing as was the case in the EU co-funded project DTV4All. ${ }^{6}$ Currently, non-verbal graphical symbols such as arrows are being tested as orientation aids in combination with subtitles in immersive settings in the EU co-funded project ImAc.

The next section uses 'Simplification method' as a parameter to classify access services that use simplification strategies emerging from the methods described. The classification focuses on how the use of such methods transforms the properties of standard access services (e.g., subtitles, audio descriptions) in terms of semiotic composition. The extent to which they support or improve understandability is excluded at this stage since understandability is intrinsic to the person and must be validated by end-users (Inclusion Europe 2009; IFLA 2010; Shardlow 2014). However, this article acknowledges its importance and includes in Section 4 a classification of E2U audiovisual content according to two parameters: (a) Validation goal and (b) Validation point in time.

A classification based on Gottlieb's taxonomy facilitates an understanding of how E2U access services may differ in their semiotic composition, identity, and channels, from the standard access services when they use verbal and nonverbal simplification methods to make AV content easy to understand.

The operationalisation of the parameter Simplification method yields two types of services according to their semiotic identity, namely verbal or nonverbal. While verbal access services may include both verbal elements exclusively or a combination of verbal and nonverbal ones, nonverbal access services are limited to nonverbal elements.

Simplification method:

- E2U verbal access services

- E2U nonverbal access services

\subsection{Semiotic composition of E2U access services}

Gottlieb's taxonomy (2005) classifies standard access services by comparing their semiotic composition with that of the original texts. The categorisation considers two parameters: a) their semiotic identity, which refers to the use

6. https://sound-advice.ie/dtv4all-eu/ 
of verbal or nonverbal codes, and b) the semiotic channels available in the communication.

As for their semiotic identity, access services can be "intrasemiotic" and subsequently employ the same verbal or nonverbal code(s) as the originalfor instance, in dubbing and subtitling (verbal-verbal)—or can be "intersemiotic" and thus use a different code(s) — as is the case with audio descriptions (nonverbal-verbal).

As for the semiotic channels, this aspect refers to the semiotic channels available to the audience. Whenever audiences can access the content through the same channels as with the original version, the access services are called "isosemiotic". If the available channels are different, they are called "diasemiotic" — e.g., subtitles convey the original (aurally delivered) content through the written (visual) channel. Lastly, semiotic channels can also be "supersemiotic" or "hyposemiotic" depending on whether there are more or fewer channels available than for the original.

Similarly, this section classifies E2U access services based on their semiotic composition. At this point, a first definition of E2U access services is proposed:

Easy-to-understand access services use simplification methods, verbal or nonverbal, to make audiovisual content accessible for users with the widest range of cognitive characteristics and capabilities.

As for their semiotic identity, while E2U nonverbal access services encompass methods that use exclusively nonverbal elements (e.g., pictogram methods), E2U verbal access services employ both methods that use only verbal codes and methods that combine verbal and nonverbal elements (e.g., PL or E2R and pictograms).

As for the semiotic channels available to the user, this taxonomy presumes that E2U access services are channel-equivalent with the standard services. In this sense, an E2U dubbed movie would use the same channels as the standard dubbed movie and, thus, be channel-equivalent. Additionally, an E2U audiobook and a standard audiobook would both be diasemiotic compared to the original. This is the case because the reader, or, better said, the listener, would perceive the information aurally, compared with the visual channel used in the original book. Another example of channel equivalence between 
a standard access service and the E2U counterpart would be when both are hyposemiotic as is the case for subtitles and E2U subtitles for persons with hearing loss. Nonetheless, the taxonomy acknowledges that the degree to which an E2U access service is channel-equivalent to the standard service depends on the sensory and cognitive capabilities of the audience.

The fact that simplification also considers additions and elaborations as strategies to enhance understandability has led in this taxonomy to include a new category named "enhancing". The name is inspired by the underlying "cognitive decoding activity" of "translations as text enhancers" as defined by Gottlieb (2005: 37). The category "Enhancing" is used to describe E2U access services that add verbal or nonverbal semantic material as a simplification strategy. This approach is complementary to the "deverbalising" and "verbalising" ones described by Gottlieb (2005: 37), which focus on replacing verbal elements with nonverbal ones. Examples of "enhancing" services are provided in the sections below.

In digital accessibility contexts, such additions already exist as is the case with so-called "extended audio description". The Web Content Accessibility Guidelines (WCAG 2.1) describe them as audio descriptions that stop the audio and video briefly to provide "critical information" that cannot be included otherwise due to time constraints (W3C 2016).

\subsubsection{E2U nonverbal services}

E2U nonverbal services use nonverbal simplification methods, ${ }^{7}$ such as pictograms, to $\operatorname{adapt}^{8}$ the audiovisual content. They are:

- intrasemiotic, when they use the same nonverbal code or codes as in the standard access service, or

7. For simplification, the term "pictogram methods or services" will be used to refer to access service that use graphical symbols, being them pictograms, ideograms, emojis, etcetera.

8. The terms "to adapt" and "adaptation" are often used in E2R contexts to describe the creation of E2U texts both either from scratch or from standard content (Inclusion Europe 2009; IFLA 2010; CEAPAT 2015). The terms refer to the changes made to a text to make "both reading and comprehension easier", as explained in the definition provided by IFLA (2010). 
- intersemiotic, when they use different nonverbal codes compared to the standard access service.

The following table shows some examples.

Table 1. Examples of nonverbal E2U access services

\begin{tabular}{|l|l|}
\hline \multicolumn{1}{|c|}{ Nonverbal E2U access services } & \multicolumn{1}{c|}{ Examples } \\
\hline $\begin{array}{l}\text { - intrasemiotic or } \\
\text { - intrasemiotic and enhancing }\end{array}$ & $\begin{array}{l}\text { Easy pictogram } \\
\text { Easy sign language }\end{array}$ \\
& Easy music arrangements \\
\hline - intersemiotic or & Easy pictogram versions of: \\
- intersemiotic and enhancing & $\begin{array}{l}\text { Intertitles, subtitles, surtitles, etc. } \\
\text { Written explanations }{ }^{10}\end{array}$ \\
& $\begin{array}{l}\text { Written summaries } \\
\text { Easy music arrangements based on other } \\
\text { nonverbal content }\end{array}$ \\
\hline
\end{tabular}

Intrasemiotic, nonverbal, E2U access services would use the same nonverbal code(s) to adapt the audiovisual content. For example; an E2U access service that uses easy pictograms to adapt a pictogram access service would be nonverbal and intrasemiotic. Similarly, an E2U access service that uses E2U sign language to adapt an access service that uses sign language would also be intrasemiotic and nonverbal. In these cases, both access services use the same signs and, thus, sign-equivalent.

Whenever the adaptation involves adding new, nonverbal material as new content to improve understandability, the E2U access services would also be "enhancing". It is this additive layer which will make EU2 services differ semantically from the standard ones. Lastly, as per definition, E2U nonverbal access services exclude intralingual and interlingual forms.

Intersemiotic, nonverbal, E2U access services would adapt the audiovisual content by either using a different nonverbal code(s) compared to the

9. Though sign language also uses verbal elements to support the nonverbal signs, the main semiotic code is considered to be nonverbal.

10. Explanations are considered here as texts that provide audiences with additional information. Explanations aim to express content. They can be visually or aurally conveyed and include informative and descriptive information. 
standard access service or by adapting verbal content, making it nonverbal. An example of the latter would be an E2U access service that provides E2U pictograms of verbal subtitles. Similarly, an E2U access service may provide an easy-music arrangement based on E2U pictogram content.

Intersemiotic, nonverbal E2U access services cannot be deverbalising or verbalising since they would then be verbal access services. However, they can be enhancing and add nonverbal semiotic material as compared to the standard access services.

To sum up, the examples show that nonverbal simplification methods such as pictograms can be used to create E2U nonverbal access services. These services would either have the same semiotic identity as the standard and, thus, be intrasemiotic or use different nonverbal codes and, thus, be intersemiotic.

Both intrasemiotic and intersemiotic types can also be "enhancing". In such cases, the amount of semantic and semiotic material would be different. Intrasemiotic E2U access services would convey the semantic load of the message by adding new material of the same kind, whereas intersemiotic ones would use different codes.

The next step towards the development of such services would be to describe them and to conduct reception studies to evaluate their acceptability and usefulness in terms of understandability, viability, and cognitive load.

\subsubsection{E2U verbal services}

E2U verbal services reach simplification by using methods that rely on verbal codes either exclusively or in combination with nonverbal elements. They can be:

- Intrasemiotic, when they use the same codes as the standard counterpart. For instance, standard intralingual subtitles and E2U intralingual subtitles.

- Intersemiotic, when the codes differ. For instance, E2U intralingual subtitles that combine text and pictograms.

Intrasemiotic E2U verbal services use the same verbal or verbal-nonverbal code(s) as the standard service. They are intralingual, when they use the same language, or interlingual, when the language differs. In both cases, they can be 
"enhancing" and add new semantic material, either of the same semiotic type and, thus, be intrasemiotic or of a different type and, thus, be intersemiotic.

Figure 1. Example of E2R intrasemiotic and intralingual subtitles ${ }^{11}$

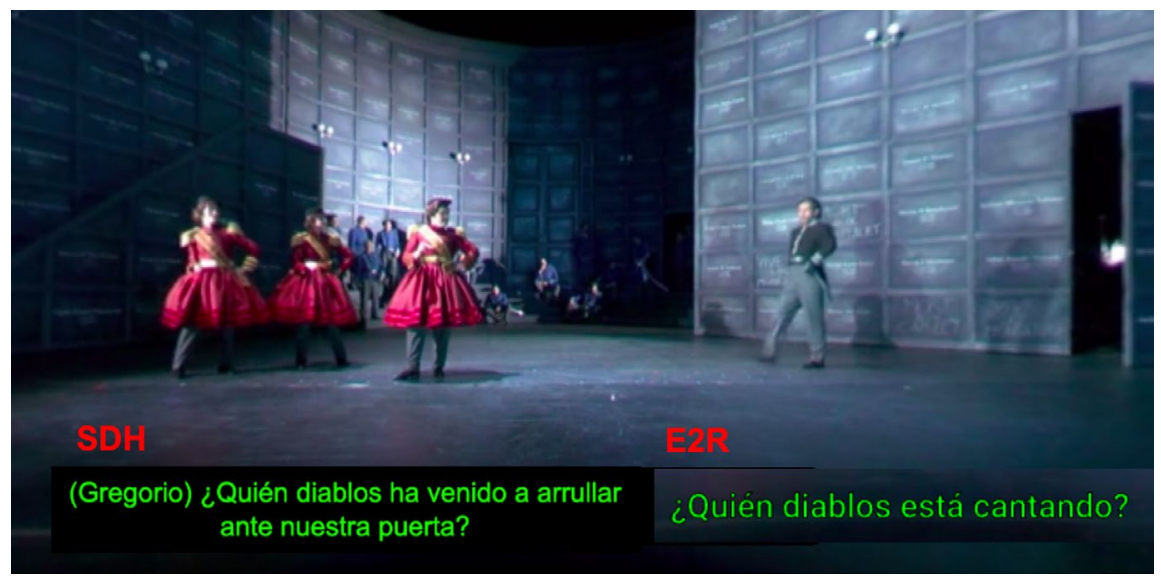

Intersemiotic E2U verbal services can emerge from either non-verbal or other verbal access services. In the first instance, E2U verbal services adapt the nonverbal audiovisual content using verbal elements and, thus, can be described as "verbalizing" (Gottlieb 2005: 37). In its role, "enhancing" elements would add verbal elements.

In the second case, intersemiotic, E2U verbal services can also emerge from adapting verbal access services by using either nonverbal elements to replace the verbal ones and, thus, be "deverbalizing" (Gottlieb 2005: 37) or by additions and, thus, be "enhancing".

For instance, intersemiotic, E2U verbal subtitles can be:

- verbalising: e.g., E2U subtitles for sign language texts.

- deverbalizing: e.g., E2U subtitles that also use nonverbal elements (e.g., pictograms), which were not part of the original subtitles.

- enhancing: e.g., E2U subtitles that describe a sculpture and provide additional background information before the actual description of the piece of art. 
The table below sums up the parameters to classify E2U verbal services.

Table 2. Classification parameters for E2U verbal access services

\begin{tabular}{|c|c|c|c|}
\hline & \multicolumn{3}{|c|}{ Verbal } \\
\hline & Plain Language & Easy to Read & Pictogram \\
\hline Intrasemiotic & \multicolumn{3}{|c|}{ intralingual, interlingual, enhancing } \\
\hline Intersemiotic & \multicolumn{3}{|c|}{ deverbalising, verbalising, enhancing } \\
\hline
\end{tabular}

The operationalisation of the parameters allows us to classify any E2U verbal access service as shown in the next table.

Table 3. Examples of E2U verbal access services

\begin{tabular}{|c|c|c|}
\hline Semiotic identity & $\begin{array}{c}\text { E2U access service } \\
\text { (auditory) }\end{array}$ & $\begin{array}{c}\text { E2U access service } \\
\text { (visual) }\end{array}$ \\
\hline $\begin{array}{l}\text { - Verbal, } \\
\text { intrasemiotic, } \\
\text { intralingual } \\
\text { - Verbal, } \\
\text { intrasemiotic, } \\
\text { intralingual, } \\
\text { enhancing }\end{array}$ & $\begin{array}{l}\text { E2U audio } \\
\text { - comment } \\
\text { - description } \\
\text { - explanation } \\
\text { - intertitles } \\
\text { - introduction } \\
\text { - subtitles } \\
\text { - summary } \\
\text { - surtitles } \\
\text { - remake } \\
\text { - sight translation } \\
\text { - voice-over }\end{array}$ & $\begin{array}{l}\text { E2U } \\
\text { - intertitles } \\
\text { - intralingual subtitling } \\
\quad{\text { (recorded })^{12}} \\
\text { - } \text { real-time intralingual } \\
\quad \text { subtitles } \\
\text { - surtitles } \\
\text { - written explanation } \\
\text { - } \text { written summary }\end{array}$ \\
\hline $\begin{array}{l}\text { - Verbal, } \\
\text { intrasemiotic, } \\
\text { interlingual } \\
\text { - Verbal, } \\
\text { intrasemiotic, } \\
\text { interlingual, } \\
\text { enhancing }\end{array}$ & $\begin{array}{l}\text { All the above as well as: } \\
\text { E2U } \\
\text { - consecutive } \\
\text { interpreting } \\
\text { - simultaneous } \\
\text { interpreting }\end{array}$ & $\begin{array}{l}\text { E2U interlingual } \\
\text { - subtitling (recorded) } \\
\text { - intertitles } \\
\text { - real-time } \\
\text { subtitling } \\
\text { - surtitles } \\
\text { - written } \\
\text { explanation } \\
\text { - written summary }\end{array}$ \\
\hline
\end{tabular}

12. Encompasses subtitles for persons with hearing loss and other audiences 


\begin{tabular}{|c|l|l|}
\hline - Verbal, & Adaptations such as: \\
intersemiotic, & Adaptations such as: \\
verbalising & pictogram to E2U audio & - pictogram to E2U \\
- Verbal, & subtitles or any of the \\
intersemiotic, & services mentioned \\
deverbalizing & an E2U audio & above \\
- Verbal, & description of a & E2U written explanation \\
intersemiotic, & or description of a \\
enhancing & & sculpture \\
& & E2U summaries of a text \\
& & which uses both verbal \\
& & elements and pictograms \\
\hline
\end{tabular}

To sum up, the use of verbal simplification methods to create E2U access services changes the semiotic identity of the standard access service in some cases. As is the case in nonverbal E2U access services, they can display either the same semiotic identity as their standard counterparts or differ when the codes are different. Equally, the amount of semantic and semiotic material may vary.

Again, the next step would be to create this material and conduct reception studies. It could be presumed that Easy to Read access services are more challenging to implement than Plain Language ones as some E2R guidelines may diverge from those of the standard access services. For example, subtitling guidelines concerning length and speed may conflict with specific E2R rules such as starting each sentence on a new line or being explicit. Such particularities demand the development of idiosyncratic guidelines for E2U services such as subtitling or audio descriptions. ${ }^{13}$

The next two tables display the classification parameters and provide examples of E2U access services according to their semiotic identity.

Table 4. Classification parameters for of E2U access services

\begin{tabular}{|c|c|c|c|c|}
\hline & \multicolumn{3}{|c|}{ Verbal } & \multirow{2}{*}{$\begin{array}{l}\text { Nonverbal } \\
\text { Pictogram } \\
\end{array}$} \\
\hline & Plain Language & Easy to Read & Pictogram & \\
\hline Intrasemiotic & \multicolumn{3}{|c|}{ intralingual, interlingual, enhancing } & enhancing \\
\hline Intersemiotic & \multicolumn{3}{|c|}{ deverbalising, verbalising, enhancing } & enhancing \\
\hline
\end{tabular}


Table 5. E2U access services

\begin{tabular}{|l|l|l|}
\hline \multicolumn{1}{|c|}{ E2U access service } & \multicolumn{1}{|c|}{ Auditory } & \multicolumn{1}{c|}{ Visual } \\
\hline $\begin{array}{l}\text { Nonverbal } \\
\text { - intrasemiotic, } \\
\text { - enhancing }\end{array}$ & Not known & $\begin{array}{l}\text { Easy pictogram } \\
\text { Easy sign language }\end{array}$ \\
\hline $\begin{array}{l}\text { Nonverbal } \\
\text { - intersemiotic, }\end{array}$ & Not known & $\begin{array}{l}\text { Pictogram-based } \\
\text { adaptations of verbal } \\
\text { access services: } \\
\text { pictogram-based intertitles, } \\
\text { subtitles, surtitles, written } \\
\text { summaries }\end{array}$ \\
\hline $\begin{array}{l}\text { Verbal } \\
\text { - intrasemiotic, } \\
\text { - intralingual or } \\
\text { interlingual, } \\
\text { - enhancing }\end{array}$ & $\begin{array}{l}\text { E2U (PL or E2R) } \\
\text { audio comments, audio } \\
\text { description, audio } \\
\text { explanation, audio intertitles, } \\
\text { audio introduction, audio } \\
\text { subtitles, audio summary, } \\
\text { audio surtitles, remake, sight } \\
\text { translation, voice-over }\end{array}$ & $\begin{array}{l}\text { E2U (PL or E2R) } \\
\text { intertitles, intralingual } \\
\text { subtitles, real-time } \\
\text { surtitles, written } \\
\text { explanations, written } \\
\text { summary }\end{array}$ \\
\hline $\begin{array}{l}\text { Verbal } \\
\text { - intersemiotic, } \\
- \text { deverbalizing, } \\
\text { - verbalizing, } \\
\text { - enhancing }\end{array}$ & $\begin{array}{l}\text { Any adaptation of pictogram } \\
\text { E2U audio access services }\end{array}$ & $\begin{array}{l}\text { Any adaptation using only } \\
\text { verbal elements or both } \\
\text { verbal and nonverbal }\end{array}$ \\
\hline
\end{tabular}

\subsection{Conclusions}

The undertaken classification shows that the semiotic identity of E2U access services is not always equivalent to that of standard access services. Moreover, it brings to light the fact that these translations as text enhancers will not always comprise the same amount of semiotic material. Given that they are inspirational translations to enhance understandability, the type of information that they convey may also be different, as previously described by Bernabé and Orero (2019b) with regard to the selection of E2U audio description cues.

The classification has also shown that E2U access services have idiosyncratic properties such as their non-standard use of language, function, and 
semiotic characteristics, which enable them beyond the "transversal property" of a given standard access service.

\section{E2U access services meet WCAG 2.1}

The increasing digital nature of audiovisual products, the high relevance of accessibility within the audiovisual media landscape, and the lack of a defined value chain for these services (European Regulators Group for Audiovisual Media Services [ERGA] 2016) calls for alignment of audiovisual access services with the Web Content Accessibility Guidelines (WCAG), in their current version 2.1 or future ones, as pointed out by Bernabé and Orero (2019; forthcoming).

WCAG are an internationally recognised set of requirements for the design of accessible digital resources on the web (W3C 2018). The guidelines result from the collaborative work by the World Wide Web Consortium's Web Accessibility Initiative (WAI) since it was founded in 1997.

The WCAG guidelines define accessibility for digital content around four accessibility principles: perceivable, operable, understandable, and robust. Each principle encompasses guidelines and sets of success criteria to test their level of conformance: A (lowest), AA, and AAA (highest). Furthermore, the guidelines provide a repository of techniques for implementation. Though compliance with WCAG does not guarantee web accessibility, they have become a recognised quality and harmonisation standard of best practices. Currently, they are adopted by laws in 21 countries, in the EU and by Section 508 of the Rehabilitation Act in the United States (Enamorado 2019).

The four accessibility principles pose different demands on audiovisual services. The 'perceivable' principle requires accessibility of content and interface elements to be made via at least two different sensory channels. 'Operability' demands the provision of input alternatives to the mouse, meaning accessibility through the keyboard or other devices that emulate them. 'Understandable' asks for meaning in terms of language and functionality at any point of the interaction. Lastly, 'robust' calls for a stable compatibility between systems and technologies by means of interoperability. 
The principles 'operable' and 'robust' are the more technical ones. However, if not considered, they might halt the interaction either partially or entirely. In this sense, a keyboard user may, for instance, be able to browse a TV show but find barriers when it comes to operating the player; in other cases, users who only have access to older technologies may be unable to interact if there is no accessibility API for communication.

'Perceivable' and 'understandable' are the principles that relate more closely to the AV modalities. The first one focuses on access through alternative sensory channels and thus already includes AV modalities such as audio descriptions, captions, or sign language. Legibility indicators are paratextual elements (Yuste Frías 2012) that support perceivability and also include: contrast, colour, size, good sound, layout, and others. Lastly, the 'understandable' principle builds upon the principles of 'perceivable' and 'operable', and capitalises on comprehension by means of improving readability, reducing the cognitive load during the interaction, and providing assistance, where necessary.

Within AVT, the principles of digital accessibility harmonise with the accessibility factors introduced by Gambier (2004). Thus: (a) legibility and synchronicity refer to the perceivability of the translation product; (b) readability, relevance, domestication, and acceptability relate to understandability; and (c) as (digital) products, they must meet user expectations (domestication) regarding the way they can be operated, the terminology used in the interface (acceptability, legibility, readability, and relevance), and the way in which they communicate with other systems-robustness-(acceptability, domestication).

As providers of an alternative way of communication (Bernabé \& Orero 2019), access services that embrace the principles of digital accessibility must, therefore, be available to the widest range of users regardless of their age, ability, and technology throughout the provision chain. From this perspective, the concept of services cannot be limited to the product, for instance, a subtitled or audio-described film, but it should rather encompass the so-called accessibility chain as defined by the Spanish standard UNE 170001-1. As the standard defines, "[t]he accessibility chain will comprise all elements 
that allow users to carry out all activities and tasks during the interaction" (AENOR 2007: 5). This approach has already been claimed by the authors Moreno, Martínez and Ruiz (2007) for digital products such as videos. In this article, this perspective is used to identify parameters to categorise the degree of accessibility of access services during the interaction, which starts at the very moment the user decides to use the service, extends throughout the provision of the access service, and expands beyond it, as it becomes part of the user experience.

The human-centred (HC) approach to the design of digital products cannot be left aside. Though the scope of this work does not allow for the exploration of this topic, it goes without saying that accessibility and Universal Design put users at the centre of their actions, as stated in their slogan: "Nothing About Us Without Us" (Zero Project 2014). Figure 2 illustrates how digital principles can be considered throughout the provision of access services and can follow a human-centred approach. 
Figure 2: HCA Accessibility chain of access services

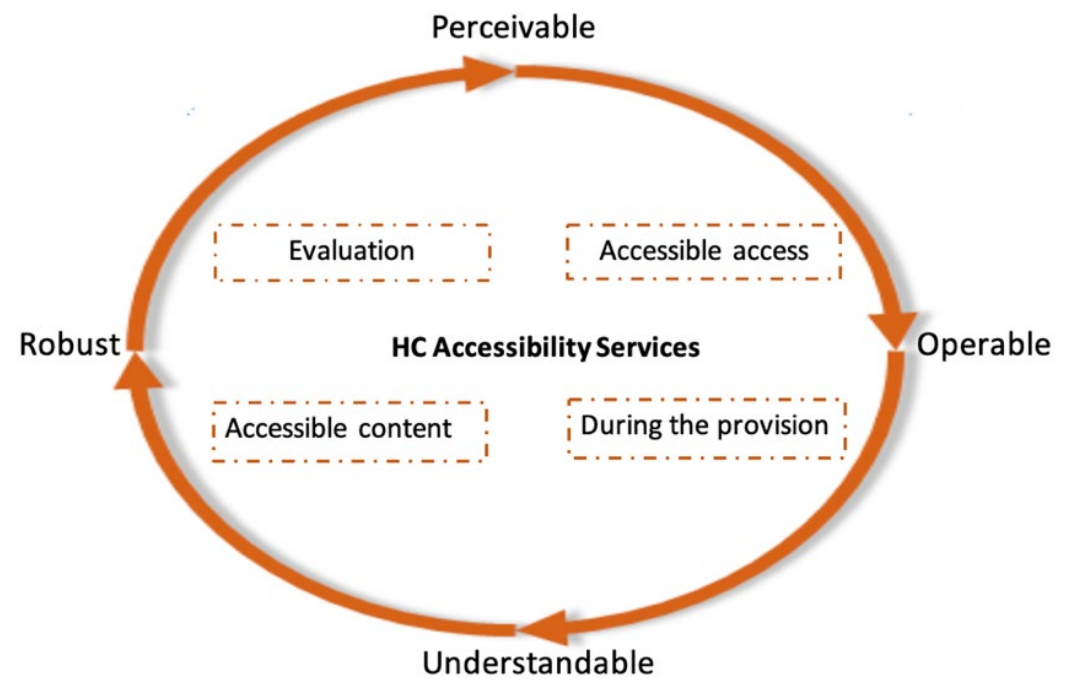

This HC approach would enable the categorisation of access services according to two parameters:

I. Degree of accessibility of the service
a. fully accessible at the different interaction stages
b. partially accessible
c. not accessible

This parameter categorises the services according to their accessibility along the accessibility chain and yields services that are either fully accessible, even if they are integrated, for instance, in a web-platform, partially accessible, or not accessible at all.

II. Degree to which the end-user is involved in the process

a. end-user involvement in the design (HCD service)

b. partial involvement of end-users in the design

c. none 
This parameter yields services that involve end-users in the design of the service. Though this parameter is considered necessary in order to align with the concept of inclusion and Universal Design, it will not be further considered in this article because it exceeds its scope. However, in the field of Easy to Read, a succinct study conducted by Bernabé (2015) showed that the design of E2R digital products often follows the principles of HC Design.

This section has related access services to digital accessibility. As a result, two parameters for categorisation have been identified, one related to the compliance with the digital accessibility principles (WCAG) throughout the provision chain, and the other one related to the underlying, human-centred approach of accessible design.

Since this article focuses on cognitive accessibility, the accessibility chain should be adapted accordingly. The next section shows how the accessibility chain can consider simplification recommendations to improve comprehension.

\subsection{Improving cognitive accessibility in the accessibility chain}

The purpose of this article is to provide a taxonomy for easy-to-understand access services. The fact that the taxonomy considers these services as digital products explains why they should be compliant with digital accessibility principles during the interaction. After this initial, more generic step, this section shows how the guidelines Information for All (Inclusion Europe 2009), easy-to-read materials (IFLA 2010), and Annex II of the German directive Barrierefreie Informationstechnik-Verordnung-BITV 2.0 (BITV 2016) already provide recommendations to improve readability, and, hence, understandability throughout the accessibility chain. These overlapping documents, authored by end-users associations and legislation, emphasise the need for an interdisciplinary effort to gather all views and knowledge in the process of developing these new services.

According to Figure 2, the service should support cognitive accessibility at access and throughout the provision, and that the content itself should be easy to understand. The recommendations are presented following this scheme. 


\subsubsection{Easy-to-understand interaction throughout the service}

Users start interacting with the system or platform at the very moment they decide to use a service. The first steps they undertake aim to locate the service, operate it, or stop the interaction if their expectations are not met at this stage. The following recommendations seek to improve the experience during the interaction by supporting cognitive accessibility.

\subsubsection{Finding the service}

Provide E2U information about:

- What contents and services are provided (DVD, web-platform, other).

- What contents and services are available in E2U.

- How to navigate and reach the E2U services.

- Who to contact for assistance.

If available through the Internet, add the keywords: Easy to Read, Plain Language, and Easy to Understand to the meta tag.

\subsubsection{Operating the service}

- Provide E2U information about how to control the player before the actual film, play, broadcast, etc. begins.

- Present the aforementioned information automatically on the screen or display it before the actual show begins.

- Provide a way (e.g., link, menu item) to return to Home at any time.

- Provide an easy way to find the information provided in E2U.

- Provide different and predictable ways of finding content.

- Try to have a way for people to find things easily.

- If available through the Internet, avoid pop-ups.

- Audio description can be switched off at any time.

- Audio subtitles can be switched off at any time.

- Subtitles can be switched off at any time.

- Speed control and rewind are available throughout the duration of the audio description. 


\subsubsection{Understanding}

- Inform the audience beforehand about the topic of the show.

- In audio descriptions, the background voice and its purpose should be introduced before the show starts.

- Choose the format (audio, written) that is best suited to its purpose; support understanding through multimodality.

- Provide E2U instructions to solve errors.

- Use E2U linguistic and design recommendations to present content.

\subsubsection{Robustness}

- Guarantee compatibility with other technologies such as screen-readers.

\subsubsection{End-user participation}

- Always find out as much as you can about the people who will use your information and about their needs.

- Take into account the information formats: written, electronic, audio and video.

- Always involve people with intellectual disabilities when creating your information.

\subsection{Conclusions}

By acknowledging E2U access service as digital products, it is possible to foster a multidisciplinary approach in their design and creation. Though digital accessibility guidelines already include access services as Success Criteria, AVT is now starting to take a more holistic view that goes beyond content creation.

This new understanding of access services will also influence the skills and competences that professionals in the field must acquire to deliver quality E2U access services. Furthermore, it will trigger the need for training and training material, and it will create new job opportunities. 


\section{E2U audiovisual content meets validation}

Plain Language and Easy to Read are user-centric simplification methods. Both recommend involving end-users in the creation process and, particularly, as validators of understandability (Inclusion Europe 2009; IFLA 2010; PLAIN 2011; García 2012; Siddharthan 2014; Plena Inclusión Madrid 2018). Validating understandability is critical in E2R contexts and recommended for PL texts (PLAIN 2011; AENOR 2018; Plena Inclusión Madrid 2018). However, this process or task does not change the nature of access services. For instance, a validated subtitle would still be a subtitle, whether E2R, PL, E2U, intralingual or interlingual.

This article acknowledges the importance of validation as a parameter to assess quality of E2U content and suggests two variables: (a) Validation goal and (b) Point in time of validation. The first enables the categorisation of E2U content according to the pursued validation goal, for example, compliance with E2R or PL rules and recommendations, text-type adequacy, or to obtain the E2R logo.

The second, Point in time of validation, locates assessment chronologically either before or after provision. From a user-centric approach, a validation that takes place before provision implies that experts or end-users have been purposefully involved in an iterative process. Conversely, a validation that is carried out after provision occurs under uncontrolled conditions. For instance, the channels are random (e.g., via social media, a feedback form, a comment on Facebook, or an email) and profile, motivation and expertise of the person remain most probably unknown. Furthermore, in this type of validation, validation results may not be implemented for reasons such as money constraints. Also, in some cases, adequacy of the proposed changes will have to be assessed prior to implementation. Due to these constraints, such validation can only be considered as "Commented validation".

As parameters, Validation goal and Validation point in time can be operationalised to differentiate the resulting categories. 
Table 6. E2U content validation

\begin{tabular}{|l|l|l|}
\hline \multirow{2}{*}{ Validation goal } & \multicolumn{2}{c|}{ Validation point in time } \\
\cline { 2 - 3 } & \multicolumn{1}{|c|}{ During creation } & \multicolumn{1}{c|}{ After provision } \\
\hline E2R-logo validation & $\begin{array}{l}\text { E2R end-user revised } \\
\text { Validated texts display the E2R logo (e.g., Inclusion } \\
\text { Europe, Netzwerk Leichte Sprache) and cannot be } \\
\text { modified afterwards without undergoing a new end-user } \\
\text { validation }\end{array}$ \\
\hline PL validation & PL end-user revised \\
\hline $\begin{array}{l}\text { Compliance with E2U } \\
\text { rules/recommendations }\end{array}$ & $\begin{array}{l}\text { - E2R revised } \\
- \text { PL revised } \\
\text { - Pictogram revised }\end{array}$ & $\begin{array}{l}\text { - E2R commented validation } \\
- \text { PL commented validation } \\
\text { validation }\end{array}$ \\
\hline Non-validated & Not validated & Not validated \\
\hline
\end{tabular}

\section{a. E2R-logo validation}

Plena Inclusión Madrid (2018) and AENOR (2018) define this type of validation as a validation that is carried out by end-users. This validation focuses on the understandability of the content during the interaction. Though it also encompasses linguistic revision of the content, it approaches style and linguistic appropriateness from a cognitive perspective. The main validators are end-users, who are supported in the process by so-called facilitators. Validated texts may display the E2R logo in compliance with the issuing organisations (e.g., Netzwerk Leichte Sprache, Inclusion Europe). After validation, these texts or services may not be changed without undergoing a new validation.

As for the point in time, this validation can be done during and after the text or the service have been created. However, until the validation has been completed and the logo issued, this validation will fall under one or several of the next types.

b. PL validation

This type of validation is equivalent to the first. However, no logo is issued because there are currently no PL logos. 


\section{c. Compliance with E2U rules/recommendations}

This validation can be undertaken by teams of persons with disabilities and facilitators, or by other professionals in E2U simplification guidelines and recommendations. For instance, a subtitler who knows E2R guidelines can validate whether readability compliance is given with regards to paratextual features (e.g., font-size, font-type, spacing) and linguistic simplification rules.

As for the point in time, this validation can take place before or after delivery. Validation after provision takes place under uncontrolled conditions. In such cases, there is no knowledge on the validator or the validating conditions nor on the purpose of the validation.

\section{d. Non-validated services}

This case yields services that have not undergone validation.

\section{Conclusions}

E2U access services can be described as inspirational translations that use language in a non-standard way and act as text enhancers to fulfil the overall goal of supporting readability and understandability of audiovisual content. The semiotic identity of the simplification methods used to create easy-to-understand content leads to changes in semiotic identity as compared with their standard counterparts. Differences bring to light idiosyncratic properties such as the use of nonverbal elements (e.g., pictograms or emojis), paratextual features (e.g., bigger font-sizes, use of the white space on the page), and prosodic ones (e.g., intonation and use of voice in audio access services). Having their own defined identity may facilitate their integration in the AVT landscape and increase their visibility.

Above all, the suggested classification should be regarded as a starting point to gather empirical data from reception studies and foster their development. Furthermore, the classification will enable the development of parameters for each service as already undertaken in the field of E2U audio description (Bernabé \& Orero 2019), E2U subtitling (Bernabé et al. forthcoming), and E2U respeaking (Eugeni \& Bernabé 2020).

The categorisation of E2U access services has also brought into light two further aspects: the role of validation and validators, and the need for access 
services that consider accessibility throughout the whole accessibility chain. The fact that understandability can only be validated by end-users also fosters the recognition of this professional role and creates new job opportunities. The compliance of digital E2U access services with the WCAG 2.1 guidelines will not only enable access for all, but it will also support the current work of the COGA.

\section{References}

AENOR. (2007) Accessibility and Design for all. Universal accessibility. Part 1: MGLC criteria to facilitate accessibility to the environment. Electronic version: $<$ https://ec.europa.eu/eip/ageing/standards/home/accessibility-and-design-all/ une-170001-12007_en>

AENOR. (2018) UNE 153101:2018 EX. Easy to read. Guidelines and recommendations for the elaboration of documents. Electronic version: <https://www.une. org/encuentra-tu-norma/busca-tu-norma/norma?c=N0060036>

Aluísio, Sandra \& Caroline Gasperin. (2010) "Fostering Digital Inclusion and Accessibility: The PorSimples project for Simplification of Portugues Texts." In: Solorio, Thamar \& Ted Pedersen (eds.) 2010. Proceedings of the NAACL HLT 2010 Young Investigators Workshop on Computational Approaches to Languages of the Americas. Los Angeles, California: Association for Computational Linguistics, pp. 46-53. Electronic version: <https://www. aclweb.org/anthology/W10-1607>

ARFÉ, Barbara; Lucia Mason \& Inmaculada Fajardo. (2017) "Simplifying informational text structure for struggling readers." Reading and Writing 31, pp. 2191-2210.

BAILEY, Kenneth D. (1994) Typologies and Taxonomies. An Introduction to Classification Techniques. Thousand Oaks: Sage.

BARTOlL, Eduard. (2008) Paràmetres per a una taxonomia de la subtitulació. Barcelona: Universitat Pompeu Fabra. Unpublished doctoral dissertation. Electronic version: <https://repositori.upf.edu/handle/10230/12088>

BATHIA, Vijay Kumar. (1983) "Simplification vs. Easification - The Case of Legal Texts 1.” Applied Linguistics 4:1, pp. 42-54.

BERENT, Irwin. (2010) "Plain Writing Legislative History - Plain Writing Association." <https://www.writersupercenter.com/plainwriting/plain-writing-legislative-history.htm> 
BERnABÉ, Rocío \& Pilar Orero. (2019) "Easy to Read as Multimode Accessibility Service." Hermeneus 21, pp. 53-74.

BERNABÉ, Rocío \& Pilar Orero. (forthcoming) "Easier audio description: Exploring the potential of easy-to-read principles in simplifying AD." In IATIS Yearbook. BERnABÉ, Rocío; Pilar Orero; Óscar García \& Estella Oncins. (forthcoming) "Creation and validation of easy-to-understand subtitles."

Bredel, Ursula \& Christiane Maaß. (2016). Leichte Sprache. Theoretische Grundlagen, Orientierung für die Praxis. Berlin: Dudenverlag (Sprache im Blick).

BurTt, Harold. (1949) "Typography and Readability." Elementary English 26:4, pp. 212-221.

CEAPAT. (2015) "Accesibilidad cognitiva." < https://ceapat.imserso.es/ InterPresent1/groups/imserso/documents/binario/reto_diez_acc_cog.pdf> Centre for Excellence in Universal Design [CEUD]. (n.d.) "What is Universal Design." <http://universaldesign.ie/What-is-Universal-Design/> CORNELIUS, Eleanor. (2010) "Plain language as alternative textualisation."

Southern African Linguistics and Applied language Studies 28:2, pp. 171-183. DOI:10.2989/16073614.2010.519106.

DíAz CinTAS, Jorge. (2004) "In search of a theoretical framework for the study of audiovisual translation." In: Orero, Pilar (ed.) 2004. Topics in Audiovisual Translation, vol. 56. Amsterdam/Philadelphia: John Benjamins, pp. 21-34.

ENAMORADO, Sofia. (2019) "WCAG 2.0: The International Standard for Web Accessibility and Inclusive Design." < https://www.3playmedia. com/2018/08/31/wcag-2-0-the-international-standard-for-web-accessibility-and-inclusive-design/>

EUGENI, Carlo. (2017) "La sottotitolazione intralinguistica automatica: Valutare la qualità con IRA." CoMe Studi di Comunicazione e mdiazione lingüistica e culturale 2:1, pp. 102-113. Electronic version: <https://www.academia.edu/7030302/ La_traduzione_audiovisiva_sottotitolazione_e_fansubbing_a_confront $>$

Eugeni, Carlo \& Rocío Bernabé. (2020) "How to simplify live subtitling: easy-to-understand respeaking as a new modality and professional profile." Unpublished manuscript.

European Commision. (2019) "Guidelines on the readability of the labelling and package leaflet of medicinal products for human use." <https://ec.europa.eu/health/sites/health/files/files/eudralex/ vol-2/c/2009_01_12_readability_guideline_final_en.pdf> 
European Regulators Group for Audiovisual Media Services (ERGA). (2016) ERGA Special Task Report on the provision of greater accessibility to audiovisual media services for persons with disabilities. Electronic version: <http:// erga-online.eu/wp-content/uploads/2016/10/report_accessibility_2016.pdf> FAJARDO, Inmaculada; Vicenta Ávila; Antonio Ferrer; Gema Tavares; Marcos Gómez \& Ana Hernández. (2014) "Easy-to-read texts for students with intellectual disability: Linguistic Factors affecting comprehension." Journal of Applied Research in Intellectual Disabilities 27:3, pp. 212-25. <DOI: 10.1111/ jar.12065>

FARJADO, Inmaculada; Gema Tavares; Vicenta Ávila Clemente \& Antonio Ferrer. (2013) "Towards text simplification for poor readers with intellectual disability: When do connectives enhance text cohesion?" Research in developmental disabilities 34:4, pp. 1267-1279. <DOI: 10.1016/j.ridd.2013.01.006>

FEAPS Madrid. (2014) "Accesibilidad Cognitiva: Guía de Recomendaciones." < http://www.plenainclusionmadrid.org/publicacion/ guia-de-recomendaciones-en-accesibilidad-cognitiva>

Gambier, Yves. (2003) "Introduction: Screentransadaptation: Perception and Reception." In: Baker, Mona (ed.) 2003. Screen Translation. Special issue of The Translator 9:2, pp. 171-189.

Gambier, Yves. (2004) "Tradaptation Cinématographique". In: Orero, Pilar (ed.) 2004. Topics in Audiovisual Translation. Amsterdam/Philadelphia: John Benjamins, pp. 169-188.

Gambier, Yves. (2013). "The Position of Audiovisual Translation Studies." In: Bartrina, Francesca \& Carmen Millán (eds.) 2013. The Routledge Handbook of Translation Studies. London: Routledge, pp. 45-59.

GARCíA, Óscar. (2012) "Lectura fácil: métodos de redacción y evaluación." $<$ https://www.plenainclusion.org>

GenetTe, Gérard \& Marie Maclean. (n.d.) "Introduction to the Paratext." New Literary History 22:2, pp. 261-272.

GERZYMisCH-ARbOGAST, Heidrun. (2005) "Introducing Multidimensional Translation." In: Gerzymisch-Arbogast, Heidrun \& Sandra Nauert (eds.) 2005. Proceedings of the Marie Curie Euroconferences MuTra: Challenges of Multidimensional Translation. Saarbrücken, pp. 1-15. Electronic version: $<$ https://www.euroconferences.info/proceedings/2005_Proceedings/2005_ GerzymischArbogast_Heidrun.pdf> 
GotTlieb, Henrik. (1992) "Subtitling: A New University Discipline." In: Dollerup, Cay \& Anne Loddegaard (eds.) 1992. Teaching Translation and Interpreting: Training, Talent and Experience. Amsterdam/Philadelphia: John Benjamins, pp. 161-170.

GotTlieb, Henrik. (2005) "Multidimensional Translation: Semantics turned Semiotics." In: Gerzymisch-Arbogast, Heidrun \& Sandra Nauert (eds.) 2005. Proceedings of the Marie Curie Euroconferences MuTra: Challenges of Multidimensional Translation. Saarbrücken, pp. 33-61. Electronic version: <https://www.euroconferences.info/proceedings/2005_Proceedings/2005_ Gottlieb_Henrik.pdf>

Gottlieb, Henrik. (2017) "Semiotics and translation." In: Malmkjær, Kirsten (ed.) 2017. The Routledge Handbook of Translation Studies and Linguistics. Electronic version: <https://www.routledgehandbooks.com/ doi/10.4324/9781315692845-4>

HeRnÁndeZ BARTOlOMÉ, Ana Isabel \& Gustavo Mendiluce Cabrera. (2005) "New Trends in Audiovisual Translation: The latest challenging modes." Miscelánea: a journal of English and American Studies 31, pp. 89-104.

HuRTADO, Amparo. (1994) "Modalidades y tipos de traducción." Vasos comunicantes 4 , pp. 19-27.

IFLA. (2010) "Guidelines for easy-to-read materials." <https://www.ifla.org/> Inclusion Europe. (2009) Information for All. European standards for making information easy to read and understand. Electronic version: <http://sid.usal. es/libros/discapacidad/23131/8-4-1/information-for-all-european-standards-for-making-information-easy-to-read-and-understand.aspx $>$

ITU. (2005) "Deadline reached for switchover from analogue to digital TV for 119 countries in Europe, Africa, Middle East and Central Asia." < http://www. itu.int/net/pressoffice/press_releases/2015/25.aspx>

JAKOBSON, Roman. (1959) "On Linguistic Aspects on Translation." In: Brower, Reuben Arther (ed.) 1959. On Translation. Cambridge, Massachusetts: Harvard University Press, pp. 232-239. Electronic version: <http://complit.utoronto. ca/wp-content/uploads/COL1000H_Roman_Jakobson_LinguisticAspects. pdf>

JOHANSSON, Stefan. (2016) Towards a framework to understand mental and cognitive accessibility in a digital context. Stockholm: KTH Royal Institute of Technology - School of Computer Science and Communication. Unpublished doctoral 
dissertation. Electronic version: <http://kth.diva-portal.org/smash/record. jsf?pid=diva2\%3A908641\&dswid=3185>

LAVIOSA-BRATHWAite, Sara. (2001) "Universals of Translation." In: Baker, Mona (ed.) 2001. Encyclopedia of Translation Studies. London/New York: Routledge, pp 288-291.

Matamala, Anna. (2007) "La audiodescripción en directo." In: Jiménez Hurtado, Catalina (ed.) 2007. Traducción y accesibilidad: la subtitulación para sordos y la audiodescripción para ciegos: nuevas modalidades de Traducción Audiovisual. Frankfurt: Peter Lang, pp. 121-132.

Moreno, Lourdes; Paloma Martínez \& Belén Ruiz. (2007) "The accessibility chain of video on the web." Electronic version: <https://www.w3.org/2007/08/ video/positions/AccessibilityChaiVideoWeb.pdf>

NiETZIO, Annika; Daniel Naber \& Christian Bühler. (2014) "Towards Techniques for Easy-to-Read Web Content.” Procedia computer Science 27, pp. 343-349.

OlivetTi Belardinelli, Marta. (2008) "Scaffolding the design of accessible eLearning content: a user-centered approach and cognitive perspective." Cogn Process 9, pp. 209-216.

Oncins, Estella; Rocío Bernabé, Mario Montagud \& Verónica Arnáiz Uzquiza. (2020) "Accessible scenic arts and Virtual Reality: A pilot study with older adults about user preferences when reading subtitles in immersive environments" In: Richart-Marset, Mabel and Francesca Calamita (eds.) 2020. Traducción y Accesibilidad en los medios de comunicación: de la teoría a la práctica. MonTI 12, pp. XXX-XXX.

OrERo, Pilar. (2011) "Audio Description for Children: Once upon a time there was a different audio description for characters". In: di Giovanni, Elena (ed.) 2011. Entre texto y receptor: accesibilidad, doblaje y traducción. Frankfurt am Main: Peter Lang, pp. 169-184.

Plain Language Action and Information Network [PLAIN]. (n.d.). "What is Plain Language?" <https://www.plainlanguage.gov/about/definitions/>

PLAIN. (2011) "Federal Plain Language Guidelines". Electronic version: <https:// plainlanguage.gov/media/FederalPLGuidelines.pdf>

Plena Inclusión Madrid. (2018) "Validación de textos en lectura fácil: aspectos prácticos y sociolaborales". Electronic version: <https://plenainclusionmadrid.org/recursos/ validacion-de-textos-en-lectura-facil-aspectos-practicos-y-sociolaborales-2/> 
Sevilla, Javier; Gerardo Herrera; Bibiana Martínez \& Francisco Alcantud Marín. (2007) "Web Accessibility for Individuals with Cognitive Deficits: A Comparative Study between an Existing Commercial Web and Its Cognitively Accessible Equivalent." ACM Transactions on Computer-Human Interaction $14: 3$, pp. 3-25.

SEwall, Sam. (2009) "The Switch from Analog to Digital TV." <https://www. nielsen.com/us/en/insights/news/2009/the-switch-from-analog-to-digital-tv. html>

SHARDLOW, Matthew. (2014) "A Survey of Automated Text Simplification." International Journal of Advanced Computer Science and Applications, Special Issue on Natural Language Processing, pp. 58-70.

SIDDHARTHAN, Advaith. (2014) "A survey on text simplification." International Journal of Applied Linguistics 165:2, pp. 259-298.

TINKER, Miles. Albert. (1963) Legibility of Print. Ames, IA: Iowa State University Press.

TOURY, Gideon. (1995) Descriptive translation studies and beyond. Amsterdam/ Philadelphia: John Benjamins.

TuseT, Pere; Juan Miguel López; Pere Barberán; Léonard Janer \& Cristina Cervelló-Pastor. (2011) "Designing Messenger Visual, an Instant Messaging Service for Individuals with Cognitive Disability." In: Bravo, José; Ramón Hervás \& Vladimir Villarreal (eds.) 2011. Ambient Assisted Living. Berlin/ Heidelberg: Springer, pp. 57-64.

VERBRAUCHERSCHUTZ, B. d. (2016) "Verordnung zur Schaffung barrierefreier Informationstechnik nach dem Behindertengleichstellungsgesetz (Barrierefreie-Informationstechnik-Verordnung - BITV 2.0). "Electronic version: <https://www.gesetze-im-internet.de/bitv_2_0/BJNR184300011.html> Verdugo, Miguel Ángel \& Robert L. Schalock. (2010) "Últimos avances en el enfoque y concepción de las personas con discapacidad intelectual." Siglo cero 41:4, pp. 7-21.

VIVED, Elías \& Santiago Molina. (2012) Lectura fácil y comprensión lectora en personas con discapacidad intelectual. Zaragoza: Prensas de la Universidad de Zaragoza.

W3C. (2016) "Extended Audio Description (Prerecorded): Understanding SC 1.2.7." <https://www.w3.org/tr/understanding-wcag20/media-equiv-extended-ad.html> 
W3C. (2018) "Web Content Accessibility Guidelines (WCAG) 2.1." < https:// www.w3.org/TR/WCAG21/>

WENGLin, Åsa. (2019) "Easy To Read and Plain Language - can we learn anything from linguistic research?" Electronic version: <http://pagines.uab.cat/easit/ en/content/event-2-presentations>

YUSTE FRÍAS, José. (2012) "Paratextual Elements in Translation: Paratranslating Titles in Children's Literature." In: Gil-Bajardí, Anna; Pilar Orero \& Sara Rovira-Esteva (eds.) 2012. Translation Peripheries. Frankfurt am Main: Peter Lang, pp. 117-134.

Zero Project. (2014) "Nothing about us without us." < https://zeroproject.org/ nothing-about-us-without-us/>

\section{BIONOTE / BIONOTA}

Rocío BERnABÉ holds an MA in Translation (UGR), MA in Accessible Documents, Technologies and Applications (UNIR) and is a PhD student in easy-to-understand media services at the Universitat Autònoma de Barcelona. She is also an external collaborator of the research group TransMedia Catalonia. She is Deputy Head of the Professional College of Translation and Interpreting of the SDI in Munich (Germany). She is the project leader of the EU co-funded project Live Text Access, which aims to create certified learning materials for real-time intralingual subtitlers by respeaking and velotyping. She is project partner, accessibility manager and leader of the Intellectual Output 2 of the EU co-funded project EASIT, Easy Access for Social Inclusion Training.

Rocío Bernabé es licenciada en Traducción (UGR), tiene un Máster en Documentos, Tecnologías y Aplicaciones Accesibles (UNIR) y está cursando el último año de su investigación doctoral en el campo de la Lectura Fácil en servicios audiovisuales de accesibilidad en la Universitat Autònoma de Barcelona. También es colaboradora externa del grupo de investigación TransMedia Catalonia. Actualmente es subdirectora de la Escuela Profesional de Traducción e Interpretación del SDI en Munich (Alemania). Es la coordinadora del proyecto europeo ERASMUS + Live Text Access, que tiene como objetivo crear un currículum y materiales de formación para subtituladores en tiempo real mediante rehablado y el teclado Veloptype. Es socia del proyecto 
europeo ERASMUS + EASIT, Easy Access for Social Inclusion Training, en el que es gestora de accesibilidad y líder del segundo paquete de trabajo, Intellectual Output 2. 